Témoigner Témoigner. Entre histoire et mémoire

Getuigen Revue pluridisciplinaire de la Fondation Auschwitz

$122 \mid 2016$

Révisionisme et négationisme

\title{
El botón de nácar: een knop in het Chileense geheugen
}

Gorik de Henau

\section{OpenEdition}

1 Journals

Édition électronique

URL : https://journals.openedition.org/temoigner/4060

DOI : $10.4000 /$ temoigner.4060

ISSN : 2506-6390

Éditeur :

Éditions du Centre d'études et de documentation Mémoire d'Auschwitz, Éditions Kimé

Édition imprimée

Date de publication : 2 mai 2016

Pagination : 13-15

ISSN : 2031-4183

Référence électronique

Gorik de Henau, «El botón de nácar: een knop in het Chileense geheugen», Témoigner. Entre histoire et mémoire [Online], 122 | 2016, Online op 30 septembre 2021, geraadpleegd op 04 janvier 2022. URL: http://journals.openedition.org/temoigner/4060 ; DOI: https://doi.org/10.4000/temoigner.4060

Tous droits réservés 


\section{EL BOTÓN DE NÁCAR: EEN KNOOP IN HET \\ CHILEENSE GEHEUGEN}

\author{
FILM In El botón de nácar heeft de \\ Chileense cineast Patricio Guzmán het \\ over een weinig bekende episode uit de \\ geschiedenis van zijn land, namelijk de \\ volkerenmoord op de Selknam en andere \\ indianenstammen in het zuiden. In 2015 \\ werd de film op het Festival van Berlijn \\ bekroond met de Zilveren Beer voor het \\ beste scenario. Een oefening in herinneren.
}

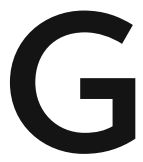

uzmán legde een indrukwekkend traject af. Hij staat vooral bekend om zijn monumentale, driedelige documentaire La batalla de Chile (1975-1979), waarin hij scherpstelde op de militaire staatsgreep in Chili in september 1973. Ook in latere films (Chile: la memoria obstinada, Le cas Pinochet, Salvador Allende) bleef hij objectiverend gericht op de recente Chileense geschiedenis. Maar met Nostalgia de la luz (2010) sloeg hij een andere, persoonlijker richting in. In een essayachtige mengvorm tussen neutraal verslag en subjectieve mijmering legde hij een verband tussen het lot van de Chilenen en de geschiedenis van het universum. Terwijl wetenschappers in de noordelijke Atacama-woestijn met telescopen naar buitenaardse hemellichamen speurden, zochten familieleden van desaparecidos (door het regime ontvoerde politieke tegenstrevers) in de onmiddellijke omgeving naar de stoffelijke resten van hun verwanten.

Met El botón de nácar (letterlijk: de paarlemoeren knoop) gaat Guzmán op dit elan door. In de film buigt hij zich over de genocide op de indianen in Vuurland, in het uiterste zuiden van Chili. Van de verschillende volken (Yahgan, Kawésqar) die daar samenwoonden, vormden de Selknam de grootste groep. Voor de komst

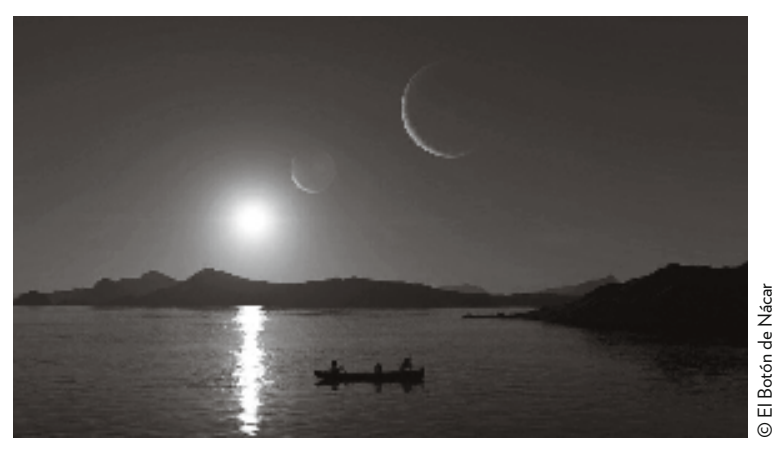

- Kano op een exoplaneet

van de blanke kolonisatoren in de tweede helft van de negentiende eeuw telden ze 3500 tot 4000 hoofden, maar via een gerichte campagne werden ze in een vijftiental jaar gedecimeerd. Van de Europese inwijkelingen kregen ze kleren die besmet waren met microben, waardoor ze ziek werden en stierven. De rest werd uitgemoord door Chileense en Engelse schutters, ingehuurd door de grote veehouders die het land wilden vrijmaken voor de schapenteelt. Als bewijs sneden ze hun slachtoffers een vinger of een oor af, want ze werden per vermoorde indiaan betaald. De paar honderd overblijvende Selknam werden opgesloten in kampen op het eiland Dawson (in de Straat Magellaan) en hun cultuur werd stelselmatig vernietigd. In de loop van de twintigste eeuw werden de schaarse overlevenden door verplichte integratie verder uitgedund. In 1974 stierf de laatste zuivere vertegenwoordiger van het Selknamvolk; het handvol nazaten dat vandaag nog in leven is, is van gemengde afkomst.

Dat zijn de feiten in een notendop. Jarenlang werden ze doelbewust doodgezwegen. Als er in Chili, het meest westerse (lees: het meest blanke) land van Latijns-Amerika, al over indianen werd gesproken, dan ging het steevast over de Mapuche in het noorden, $\bullet \bullet$ 
• of over de indianen verder weg, op veilige afstand in Peru en Bolivia. De oorspronkelijke bewoners in het zuiden van het land werden als Fueguino's omschreven (mensen van Tierra del Fuego of Vuurland), een soort mythisch volk zonder stem of geschiedenis. Dat een aantal van hen was uitgemoord, daarover werd in de Chileense media en het onderwijs met geen woord gerept. Pas vandaag begint het bewustzijn van de genocide door de dringen bij bredere lagen van de bevolking. El botón de nácar sluit aan bij dit terugdraaien van de bewuste amnesie.

Veeleer dan een klassieke documentaire met plaatjes en talking heads maakt Guzmán er opnieuw een hybridisch essay van. Hij neemt een lange aanloop, een soort captatio benevolentiae waarmee hij de nietsvermoedende kijker uitnodigt om over de drempel van zijn film heen te stappen. We zien een hand die een blok kwarts tegen het licht houdt en het laat wentelen. Binnenin beweegt een druppel, meteen het begin van een lofzang op het water. In Vuurland ging Guzmán prachtige beelden draaien van ijsrotsen, ijsbergen, gletsjers en besneeuwde bergruggen. En van water: rimpelend, bruisend, stromend, klaterend water. Het universum, de aarde, de mens bestaan voor het grootste deel uit water, zo leren we uit de lijzige commentaarstem van de regisseur zelf. Het langgerekte Chili is grotendeels door water bepaald, de Stille Oceaan vormt er de langste grens van. De inheemse volkeren leefden in en om het water, plukten er de vruchten van en wisten hoe ze met de gevaren ervan moesten omgaan.

Na die inleiding komt Guzmán ter zake. We krijgen een reeks interviews te zien met Chilenen van indiaanse afkomst. Ze vertellen over hun jeugd, hun ervaringen met water, hoe je een kano bouwt. Ze vertalen Spaanse woorden naar hun eigen talen, die intussen in de verdrukking zijn geraakt. Want het blijkt te gaan om nakomelingen van slachtoffers van de volkerenmoord. Een van hen is de 75-jarige Gabriela Paterito, de belangrijkste getuige in de film. Dan maakt Guzmán een sprong naar de slachtoffers van de repressie onder generaal Pinochet. Met financiële en materiële steun van de Verenigde Staten pleegde die op 11 september 1973 een staatsgreep, waarbij de democratisch verkozen president Salvador Allende werd vermoord. Pinochet installeerde een militaire dictatuur met zichzelf aan het hoofd. Sommige opposanten van het regime kwamen ook weer op het eiland Dawson terecht. Anderen wer- den in zee geworpen, waar ze door het water werden opgeslokt. Maar in 1970 kwam opeens het lijk van een vrouw bovendrijven. In de pers was sprake van een passiemoord, maar de onderzoeksrechter begreep al snel dat die verklaring niet klopte. Na het einde van de dictatuur liet hij een nieuwe autopsie uitvoeren, waaruit bleek dat ze was versmacht.

Uiterst nauwgezet, als in een juridische reconstructie, ensceneert Guzmán hoe het hele proces in zijn werk ging. Het hypothetische slachtoffer, voorgesteld door een levensgrote pop, wordt gewurgd met ijzerdraad, verzwaard met een treinrail, ingepakt metjuten zakken, ingeladen in een legerhelikopter en vervolgens in de Stille Oceaan gegooid. Per vlucht werden acht tot tien slachtoffers uitgeworpen, zo leren we. Waarschijnlijk was de bewuste vrouw tijdens de vlucht weer bijgekomen, waarop ze alsnog werd vermoord en overhaast (dus zonder treinrail) overboord gegooid. Guzmán dwingt de toeschouwers de procedure van nabij te volgen, geen enkel morbide detail blijft hun bespaard. Je kunt er een strategie in zien om ontkenners de pas af te snijden, om mensen die liever de andere kant opkijken methun neus op de feiten te drukken. Want het medium film is voor Guzmán geen voertuig voor licht verteerbaar vertier, het is een middel om de werkelijkheid en de geschiedenis door te lichten. Hij vermaakt niet, hij gaat op onderzoek en brengt verslag uit. De helikopter die je te zien krijgt, is trouwens niet van het leger; het is een helikopter die speciaal voor de film als een militair toestel werd uitgedost. Het Chileense leger hanteert immers de tactiek van de volledige ontkenning. Het beweert dat de hele zaak een verzinsel is en stelt nooit te zullen meewerken aan een onderzoek. Maar de monolithische militaire burcht begint barsten te vertonen,

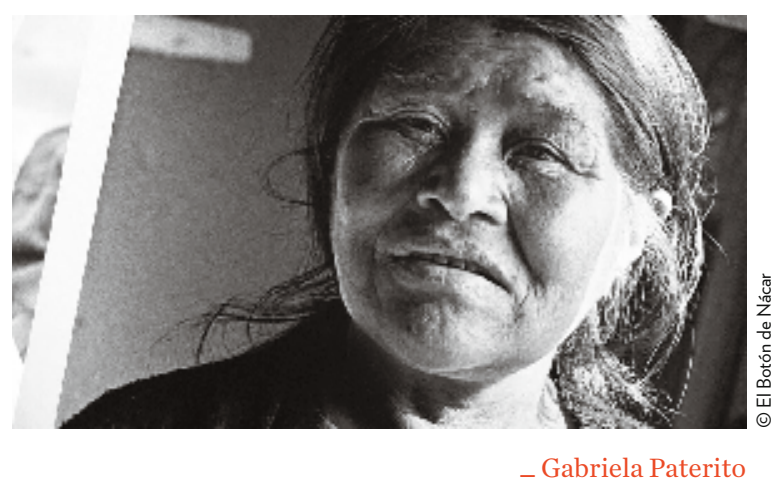

Getuigen tussen geschiedenis en herinnering - nr. 122 / april 2016 


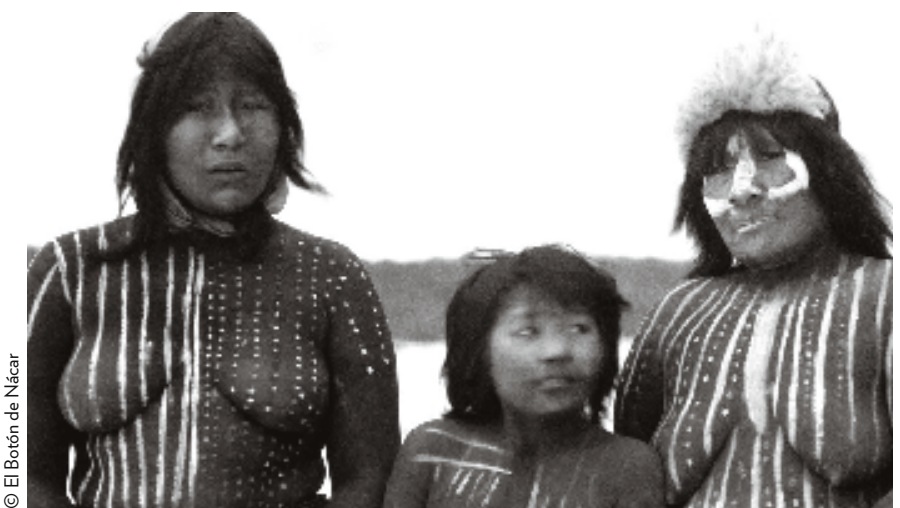

_ Selknamvrouwen, rond 1930

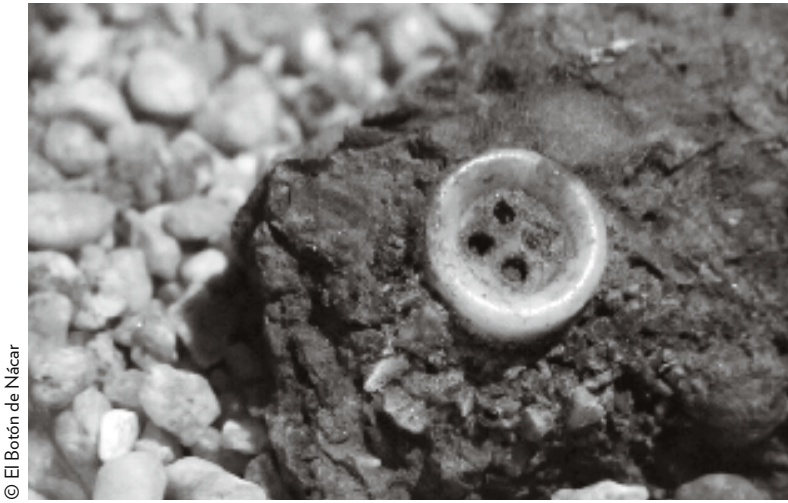

_ Paarlemoeren knoop van 'Jemmy Button', gevonden op een trainrail voor de kust van Chili want intussen praatten verschillende lagere officieren hun mond al voorbij.

In het water komen beide verhaallijnen van El botón de nácar samen. Begin jaren 1980 werd de zeebodem voor de Chileense kust, vlakbij de luchtmachtbasis van Quintero, systematisch onderzocht, waarbij tientallen treinrails werden opgedoken. Op een van hen zat een knoop. Guzmán zag hem in het museum in Santiago de Chile waar hij zich nu bevindt en zo ontstond het concept voor de film. De cineast associeerde de knoop met Jemmy Button (Engels voor Jaap Knoop), de lokale indiaan die halverwege de negentiende eeuw door Britse ontdekkingsreizigers naar Engeland werd getransporteerd, waar hij een jaar als beroemdheid doorbracht alvorens naar Vuurland terug te keren. De prijs die de Britten voor hem betaalden was een paarlemoeren knoop, vandaar zijn bijnaam en de titel van de film.

Opvallend is het gebruik dat de cineast maakt van zwart-witfoto's uit het begin van de twintigste eeuw. Die werden genomen door Martin Gusinde, een Duits priester-antropoloog die in Chili werkte. Vanuit Punta Arenas ondernam hij vier expedities naar de zuidelijke eilanden, waar hij meer dan duizend foto's nam. Tegenwoordig zijn ze in het bezit van een Duitse instelling, die ze ter beschikking stelde van Guzmán. Op de foto's zien we spiernaakte indianen, beschilderd met een reeks mysterieuze symbolen die verwijzen naar de Melkweg, de maan en de sterren. Volgens antropologen zou het om een inwijdingsritueel gaan, hoewel daarover geen uitsluitsel bestaat. De foto's worden door de cineast vermengd met interviews, getuigenissen en archiefbeelden. Overweldigende ruimtegezichten worden afgewisseld met enigmatische shots van de reusachtige telescopen in de Atacama-woestijn die onafgebroken het universum afspeuren op sporen van water - een passage die wel uit een sciencefictionfilm lijkt geknipt.

Naast diverse Chilenen van indiaanse afkomst komen nog andere getuigen aan het woord of in beeld, bijvoorbeeld de antropoloog-musicus Claudio Mercado die letterlijk de lof van het water zingt, de beeldend kunstenaar Emma Malig die een schaalmodel van de eindeloze Chileense kust maakt, de dichter Raúl Zurita die met metafysische methodiek de militaire misdaden tegen de mensheid aanklaagt, de journalist Javier Rebolledo die twee boeken publiceerde over de infame helikoptervluchten, een helikoptermecanicien die uit de biecht klapt. Het bindmiddelvan dit alles is de warme stem van Guzmán, die in een voice-over verwoordt wat hem in zijn filmische essay motiveert. En zo belanden we bij de paradox van de film, want net door dat commentaar wordt het verhaal met een caleidoscoop van zeer divers beeldmateriaal een intens persoonlijk document. De cineast verbindt micro- met macrokosmos, de mens met de natuur, het kleine verhaal met de grote Geschiedenis. Het resultaat is een wondermooi filmgedicht dat niet alleen ontroert, maar de toeschouwer ook op weg zet naar een vergeten bladzijde uit de geschiedenis.

Gorik de Henau 